\title{
Factors Affecting Fishers' Attitude and Willingness to use Cage Aquaculture as an Alternative Livelihood for Reducing Fishing Pressure in Haor Areas, Bangladesh
}

\author{
SHAHIDUL ISLAM BHUIYA ${ }^{1}$, MOHAMMAD BODRUL MUNIR ${ }^{* 2}$, MD. ABDUL HANNAN $^{3}$, \\ FOZLUL KABEER $^{1}$, MD. JAMAL HOSSAIN ${ }^{4} \&$ AKM NOWSAD ALAM ${ }^{4}$ \\ ${ }^{1}$ Department of Fisheries (DoF), Bangladesh; ${ }^{2}$ Faculty of Resource Science and Technology, Universiti \\ Malaysia Sarawak, 94300 Kota Samarahan, Sarawak; ${ }^{3}$ Dept. of Aquatic Animal Health Management, Sher-e- \\ Bangla Agricultural University, Bangladesh; ${ }^{4}$ Dept. of Fisheries Technology, Bangladesh Agricultural \\ University, Mymensingh-2202, Bangladesh \\ *Corresponding author: mmbodrul@unimas.my \\ Received: 15 October 2021 \\ Accepted: 6 December 2021 \\ Published: 31 December 2021
}

\begin{abstract}
Inland capture fisheries are providing cost of livings of about 1.2 million BDT in Bangladesh. However, overexploitation causes the declination of the abundance of native fish species which adversely affects the livelihoods of haor dwellers. The present study was conducted in two haor villages (Sutarpara and Changnoagaon) of Kishoreganj, Bangladesh to explore the factors (economic and non-economic) affecting fishers' attitude and willingness about cage aquaculture considered as livelihood alternative for reducing fishing pressure. The methodologies applied to do this study were semi-structured face-to-face interview, key informants and questionnaire survey using Likert scale (LS), focus group discussions (FGD). The result revealed that willingness to switch from traditional way of fishing to cage aquaculture activities was significantly $(\mathrm{p}<0.05)$ higher in those fishers' groups that had more inclination in fishing activities. Simultaneously, non-economic factors like powerful traders and fishers, traditional belief, taking risk, launching period of cage aquaculture venture and investment duration played vital role in decisions on whether to fish or not. The economic factors were fewer in number than non-economic factors. This comparative research is significantly important for future social aquaculture researchers as well as the country policy makers for giving emphasis to gather data based on the prevailing economic and non-economic factors to innovate alternative livelihood activity concurrently.
\end{abstract}

Keywords: Cage aquaculture, economic and non-economic factors, Likert scale, FGD, Changnoagaon, Sutarpara haor

Copyright : This is an open access article distributed under the terms of the CC-BY-NC-SA(Creative Commons Attribution-NonCommercial-ShareAlike 4.0 International License) which permits unrestricted use, distribution, and reproduction in any medium, for non-commercial purposes, provided the original work of the author(s) is properly cited.

\section{INTRODUCTION}

The global dense population lead to overexploitation of traditional ecosystem in the world which includes the fishing sector that increased $33.1 \%$ fishing pressure of world fish stocks are as well subject to overfishing (SOFIA 2018). Over 160 million people lead their livelihood based on the available natural resources in Bangladesh of which $12 \%$ are heavily and lightly depending on the fisheries resources (Shah, 2003). Therefore, the inland and marine fisheries (closed and open) had a production volume of 4.13 million metric tons in 2016-2017 (SOFIA 2018). The capture fisheries production in Bangladesh is decreasing due to overexploitation and other associated reasons like habitat destruction and water pollution. The aquaculture production in Bangladesh has increased over the years because this sector has adopted some dynamic innovative aquaculture technologies. The community based cage aquaculture in open and closed waterbodies is one of them.

The fishing communities are changing their livelihood from traditional wild fishing to agriculture with other example of daily incomeoriented works. Moreover, the decreasing of fish resources compels the fishers in difficulties who rely on fishing only (Alam \& Basha, 1995, Rejwan et al., 2012). The current and unexpected situation is the result from the introduction of destructive fishing gears and methods along with the illegal fishing (catching mother fishes, habitat destroy, 
pollution and larger nets with small mesh-sizes) in fishing communities over the past decades (Chaki et al., 2014; DoF, 2015). Meanwhile in the haor (a bowl or saucer shaped shallow depression wetland ecosystem), the major threats to the future resources of wild stock are from overfishing and illegal fishing. Fortunately, continuous fresh water flows adjacent to the fishers' community thus requires the provision of livelihood alternatives (cage aquaculture) that are readily accepted by fishers' community which in return space catch intensity on the wild stock (Adibashi Fisheries Projects, 2007; Rahman, 2004).

In general, the factors related to individual fisher (their attitude and willingness) and community socio-economic (economic status and social leadership) condition as a whole affect the likelihood of technical adoption of any new technology like cage aquaculture in the haor area. In recent time, the fishing community doesn't always rely mainly on catching wild fish but often prefer to expand their livelihood portfolio to comprise activities such as agriculture/farming, day labor basis in brickfield. In the research areas, during winter a remarkable number of fishers join in the paddy fields and brickfields looking for alternative income generating activities which ultimately enhance the diversification of another income source.
Ample of research has been conducted individually either on technical feasibility of cage aquaculture for the community or attitude to the common people towards cage aquaculture. It is a matter of fact that the factors affecting the attitude and willingness towards cage aquaculture, but the research on technical feasibility by exploring the factors affecting the attitude and willingness of fishers towards cage aquaculture are so far been unavailable. The present study thus was carried out for highlighting these two important aspects mainly getting comprehensive information for future feasibility and sustainability of community driven cage aquaculture in haor areas in Bangladesh.

\section{MATERIALS AND METHODS}

\section{Study Area}

The experiment was conducted in Haor waters (exclusively open area) located at the Sutarpara and Changnoagaon (Figure 1) villages (Connected with Ujan Dhanu Jalmahal), Karimganj Upazila (Subdistrict, Figure 1C) of Kishoreganj district (Figure 1B) in Bangladesh (24027' 40.97" N; 90058' 16.61" W, Figure 1A). This is one of the biggest floodplain area of the North East Bangladesh. Both villages are $2 \mathrm{~km}$ far from a potential river port named Chamta Bandar.
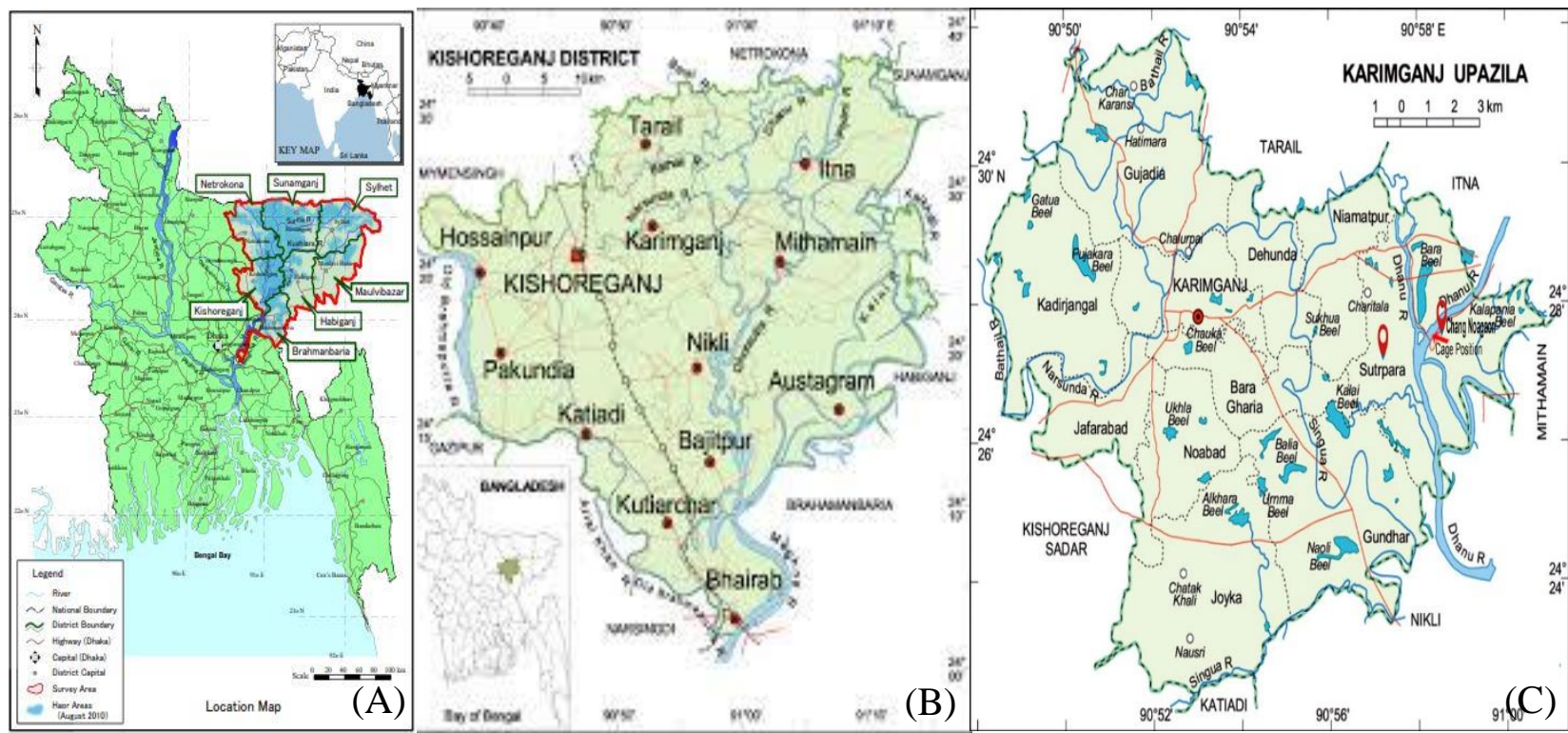

Figure 1. Studied haor area (A) Haor districts of Bangladesh; (B) Kishoreganj District; and (C) Karimganj upazila 


\section{Participants' Selection Criteria for Interview}

The respondents for interview in this study were selected from the two haor villages using opportunistic sampling method which comprised of a set of semi-structured questionnaire (quantitative and qualitative) to avoid the biasness (Kemper et al., 2003). Quantitative questionnaire survey was conducted 1) to obtain background information and in depth understanding of present local circumstances, and 2) to filter research questionnaire followed by qualitative assessments. In qualitative questionnaire survey, the special emphasis has been to get the reply on statements indicating what and how the phenomenon occurred (Flick, 2009).

\section{Questionnaire and Data Collection}

The research questionnaires were developed with special attention to examine the potential for successful community driven cage aquaculture addressing the non-economic and economic factors. Table 1 describes these factors setting some specific criteria.

Questions were set to study attitude towards cage aquaculture after classifying into four groups: employment, aquaculture, environment and health nutrition. For that reason, each group contains number of questions which help to get in depth knowledge from different angle. The same sets of questions were used to get the information from both the research sites (Table 2).

The research highlighted the preconditions (attitudes and factors) required for community driven cage aquaculture projects intending to enhance sustainability aspects where individual fishers' attitude, willingness and factors were considered carefully. The approach ensured crossvalidation of the limited quantitative outputs and helped to subsequent research projects. Additional informative data were also recorded while doing survey.

All the quantitative and qualitative data were collected by using participatory rural appraisal (PRA) techniques through semi-structured interviews, Likert scale questionnaire, focus groups, non-participant's observation, which mostly generated categorical data. These were collected from November 2013 to February 2014 (15 continuous days from each subsequent month).

The quantitative questionnaire surveys involved 53 respondents (42 fishermen and 11 women fishers) from Changnoagaon haor village and 67 respondents (54 fishermen and 13 women) from Sutarpara haor village in the side. Furthermore, discussions with two homogenous focus groups had been done where one exclusively is with fishermen and another exclusively is with fisher women at each research site. Other than validation, stakeholder analysis was also performed to examine the interest and influence of all groups of stakeholders by whom the project activities might be at risk (Bunce et al., 2000).

Three focus group discussions (FGD), each with 3-5 interviewees out of 120 participants had been conducted and accomplished. The results in percentage format are 7.9\% in Sutarpara and 5.4\% in Changnoagaon as the total number of respondents was relatively low in both research sites. Thus, the data obtained from the interviews are deemed to provide a reasonably good idea of the prevailing attitudes and willingness towards cage aquaculture introduction in haor areas.

Table 1. Non-economic and economic factors selection criteria in the study

\begin{tabular}{ll}
\hline Factors & Factors selection criteria \\
\hline Non-economic & - Which factors in terms of age groups and gender exist in the local communities, and \\
& what are their implications for cage aquaculture implementation? \\
& - Are there specific stakeholders (i.e. aratder in bangla or (whole seller), fish retailer, \\
& local elites etc.) relations to potentially affecting research activities? \\
- What are the general attitudes of local fishing communities toward cage aquaculture? & - Would fishers invest and implement cage aquaculture ventures for financial gain? \\
\hline Economic & - Are the local women fishers involved in fishing and willing to additionally install cage \\
& and accept the culture approach? \\
& Are fishers with multiple livelihood sources more willing to cage aquaculture than \\
& fishers'with only one income source?
\end{tabular}


Table 2. Set of questions to study attitude towards cage aquaculture (CA)

\begin{tabular}{|c|c|c|c|c|c|}
\hline Category & $\begin{array}{l}\text { Strongly } \\
\text { agree }\end{array}$ & Agree & $\begin{array}{l}\text { Neutral (Neither } \\
\text { agree or disagree) }\end{array}$ & Disagree & $\begin{array}{l}\text { Strongly } \\
\text { disagree }\end{array}$ \\
\hline \multicolumn{6}{|c|}{ Employment } \\
\hline $\begin{array}{l}\text { Will CA create new opportunities for } \\
\text { occupation? }\end{array}$ & 5 & 4 & 3 & 2 & 1 \\
\hline $\begin{array}{l}\text { Will CA add a healthy aqua-produce } \\
\text { business for young? }\end{array}$ & 5 & 4 & 3 & 2 & 1 \\
\hline $\begin{array}{l}\text { Will CA create new occupation for } \\
\text { women? }\end{array}$ & 5 & 4 & 3 & 2 & 1 \\
\hline Will CA create business entrepreneur? & 5 & 4 & 3 & 2 & 1 \\
\hline \multicolumn{6}{|c|}{ Aquaculture } \\
\hline $\begin{array}{l}\text { Will CA be considered as great good } \\
\text { idea? }\end{array}$ & 5 & 4 & 3 & 2 & 1 \\
\hline $\begin{array}{l}\text { Will CA create problem in local fishing } \\
\text { communities? }\end{array}$ & 5 & 4 & 3 & 2 & 1 \\
\hline Will CA affect to the wild fishers? & 5 & 4 & 3 & 2 & 1 \\
\hline $\begin{array}{l}\text { Will CA be good as an alternative } \\
\text { livelihood option? }\end{array}$ & 5 & 4 & 3 & 2 & 1 \\
\hline $\begin{array}{l}\text { CA, Will ensure healthy aqua- } \\
\text { production? }\end{array}$ & 5 & 4 & 3 & 2 & 1 \\
\hline $\begin{array}{l}\text { CA based Aqua-produce will have high } \\
\text { demand? }\end{array}$ & 5 & 4 & 3 & 2 & 1 \\
\hline $\begin{array}{l}\text { Are fishers habituated with CA, aqua- } \\
\text { production? }\end{array}$ & 5 & 4 & 3 & 2 & 1 \\
\hline CA, benefits>demerits? & 5 & 4 & 3 & 2 & 1 \\
\hline $\begin{array}{l}\text { CA, Will decrease overfishing } \\
\text { practiced? }\end{array}$ & 5 & 4 & 3 & 2 & 1 \\
\hline $\begin{array}{l}\text { CA, Will decrease unwanted by-catch of } \\
\text { fishes? }\end{array}$ & 5 & 4 & 3 & 2 & 1 \\
\hline $\begin{array}{l}\text { CA, Will help to produce more fresh } \\
\text { fish than pond produced fish thus opens } \\
\text { export quality fish? }\end{array}$ & 5 & 4 & 3 & 2 & 1 \\
\hline $\begin{array}{l}\text { CA, Will help to produce hapa nursing } \\
\text { alternative to pond nursing? }\end{array}$ & 5 & 4 & 3 & 2 & 1 \\
\hline CA, Will acts as a sanctuary? & 5 & 4 & 3 & 2 & 1 \\
\hline \multicolumn{6}{|c|}{ Environmental issues } \\
\hline $\begin{array}{l}\text { CA, Will create less damage to } \\
\text { environmental? }\end{array}$ & 5 & 4 & 3 & 2 & 1 \\
\hline $\begin{array}{l}\text { CA, Will enhances high risk of disease } \\
\text { in wild stock? }\end{array}$ & 5 & 4 & 3 & 2 & 1 \\
\hline $\begin{array}{l}\text { CA, Will cause water quality } \\
\text { deterioration? }\end{array}$ & 5 & 4 & 3 & 2 & 1 \\
\hline $\begin{array}{l}\text { CA, Will ensure traceability of the aqua- } \\
\text { produce? }\end{array}$ & 5 & 4 & 3 & 2 & 1 \\
\hline \multicolumn{6}{|c|}{ Health nutrition } \\
\hline $\begin{array}{l}\text { CA, Will be essential for protein } \\
\text { supplementation? }\end{array}$ & 5 & 4 & 3 & 2 & 1 \\
\hline $\begin{array}{l}\text { CA, Will enhance knowledge in } \\
\text { sanitation in sanitation and hygiene? }\end{array}$ & 5 & 4 & 3 & 2 & 1 \\
\hline CA, Will reduce health expenses? & 5 & 4 & 3 & 2 & 1 \\
\hline
\end{tabular}




\section{Statistical Analysis}

Categorical data gathered from the interviews ( $\mathrm{n}$ $=120$ ) were analyzed using SPSS (version-22) according to the method of Steel and Torrie (1980) (SPSS, Inc., Chicago, Illinos, USA) for each research site (Changnoagaon and Sutarpara). Cronbach's alpha test was used to identify the consistency available within the group in both research sites. Pearson's correlation coefficient was applied to identify the correlation between scale pairs. Analysis of variance, ANOVA was used to test differences in the mean value of four scale grouping.

\section{RESULTS}

Factors affecting fishers' attitude in community driven cage aquaculture are summarised in the paragraphs below.

\section{Non-economic Factors}

\section{Powerful Fisher Stakeholders}

It included the fish traders, fisheries trade organizations, local elite fishers, local fish money lenders, fish dipo or aratders (in bangla) or whole seller, community-based fisheries organizations, etc. The study revealed that these powerful fisher stakeholders from both villages where this study conducted was the significant decision makers to introduce community driven cage aquaculture. The lesser influential community fishers were suppressed by the more powerful and influential fishers' group that were found in both research sites. However, there were few participants who acknowledged that they were given opportunity to form their own group to continue the cage aquaculture activities. In return, the influential group had shown intention to contribute to the project demand in sharing the operational cost. Because of their great connection to fisheries, they had great interest in putting efforts into research aimed at reducing the fishing pressure and augment the livelihoods of traditional fishers. Table 3 illustrated how these relations prevailed in the fishers' community indicating negative affiliation was observed in most cases where the studies were conducted while, common interest from the same natural resources in different stakeholder faction was available.

\section{Traditional Belief and Good Manner}

A significant number of fishers, $51.88 \%$ for Sutarpara and $56.43 \%$ for Changnoagaon, thought this traditionally believed that fishing was the main income source.

\section{Traditional and Cultural Values}

The most common interpretation why fishers would continue both things rather than stop fishing ( $\mathrm{n}=30$; multiple answers possible) was the high traditional and cultural value of this source of income (44.77 and $30.18 \%$ ) which has provided a livelihood for these haor areas communities for last couple of decades in Sutarpara and Changnoagaon, respectively.

\section{Age Group}

Fishers belong to younger group (18-40 years) showed positive attitude and high willingness to new innovative cage aquaculture by all sort of physical and mental support compared to aged group ( $>40$ years).

\section{Gender}

The survey result revealed that there were no significant difference in sex group for studied two villages. Interest in cage aquaculture among male fishers $(n=120)$ differed insignificantly between both villages (Chi-square test, $x^{2}=10.064, \mathrm{df}=2$, $\mathrm{p}=0.067)$. Interest was very high in Sutarpara, where $83.58 \%$ of the male fishers showed 'high' willingness along with existing occupation, compared to Changnoagaon, where the interest was about $75.47 \%$. Women of these two villages helped voluntarily their fisher husbands works,

Table 3. Relations prevail in the fishers' community

\begin{tabular}{lll}
\hline Fishers & $\begin{array}{l}\text { Powerful fish } \\
\text { traders }\end{array}$ & $\begin{array}{l}\text { Long-term business, unprofitability, low trust and willingness to co-operate } \\
\text { aratders, less amount of fish delivered to the aratders }\end{array}$ \\
\hline Fishers & $\begin{array}{l}\text { Powerful and or } \\
\text { interested } \\
\text { fishers }\end{array}$ & $\begin{array}{l}\text { Abuse of power in decision making processes to get economic advantages, } \\
\text { slightly lower connection to fisheries related activities as a means of income } \\
\text { generation activities }\end{array}$ \\
\hline
\end{tabular}


Nevertheless, the interest in cage aquaculture among the women was $100 \%$ and no significant difference were observed between both the villages was found.

\section{Education}

The study found that the fishers having elementary level of education did not take risk to do the new technology like cage aquaculture. However, the people having higher level of education (more than class nine in the school) showed positive interest on this. This trend was very common in both the villages.

\section{Investment Tenure}

About 55\% of respondents did not support about the facility of long term output based investment. They showed their affiliation towards short term investment in Changnoagaon. But significantly higher $(p<0.01)$ percent of fishers in Sutarpara agreed with short term investment rather than long term investment. Notably, all respondents in this study indicated the project launching time probably due to natural fish catching time which causes dramatic reduction of market price of cultured fish.

\section{Economic factors}

\section{Urban migration}

According to the output from the focus group discussions, approximately 2-3 percent fishers migrated from the studied area to improve their present status of living. These have seemed to be negative impact on the community driven cage aquaculture.

\section{Paddy Planting}

All interviewees opined that paddy planting was the major agricultural activity prevailing in the fishers' community to adopt the new community driven cage aquaculture. Among the selected interviewees (120), 67.55\% interviewee have the agricultural paddy land. A significant number of fishers $(23.21 \%)$ having paddy field in remote areas and they usually go there for several months (planting to harvesting).

\section{Alternative Income Source}

Approximately, $26.46 \%$ and $31.34 \%$ villagers in Changnoagaon and Sutarpara, respectively, supported the alternative income source. In Changnoagaon, $22.68 \%$ of the asked community fishers were willing to quit wild fish catching and were solely dependent on cage aquaculture, while in Sutarpara about $20.89 \%$ showed the same willingness. Cage aquaculture and wild fish catching, both were preferred by a significant percentage of community fishers in the case of both research sites where $77.32 \%$ of respondents in Changnoagaon and $79.11 \%$ in Sutarpara.

\section{Factors Affecting Fishers' Willingness About Community Driven Cage Aquaculture}

\section{Reliability Analysis}

Table 4 shows the reliability of each set of scales. In Sutarpara, questions of four groups, three most reliable scales were attitude towards employment, environment and health nutrition Cronbachs' $\alpha=0.94, \quad$ Cronbachs' $\alpha=0.84$ and Cronbachs' $\alpha=0.81$ accordingly. On the other hand, attitude towards aquaculture comparatively low Cronbachs' $\alpha=0.70$. For example, the mean value of the four scales, attitude towards aquaculture was $3.56(+0.55)$ which was lower than employment and health nutrition but not significant $(p>0.05)$. Overall, Sutarpara respondent expressed the highest level of agreement with statement supporting alternative livelihood as considering employment mean $3.71(+0.52)$ and $4.02(+0.48)$ for health nutrition. Question related to environment elicited the lowest level of agreementmean $2.87(+0.41)$ which was significantly lower other than three.

In Changnoagaon, reliability analysis was conducted previously used the same four scale categories. Attitude towards aquaculture showed the highest score Cronbachs' $\alpha=0.81$ followed by employment and environment Cronbachs' $\alpha=0.75$. The last and rest scale was Cronbachs' $\alpha=0.64$. The mean value of the four scales, attitude towards employment, aquaculture, environment and health nutrition were $4.09( \pm 0.52), 3.85( \pm 0.55), 3.69$ $( \pm 0.44)$ and $4.41( \pm 0.48)$ but none of them was significant different among themselves $(\mathrm{p}>0.05)$.

The main difference between the Sutarpara and Changnoagaon reliability analysis relates to the scale grouping for health nutrition where the mean value was significantly higher for the case of Changnoagaon than Sutarpara. In contrast, the Cronbachs' $\alpha=0.64$ was observed in scale group - 
Table 4. Reliability analysis for measuring the willingness (Cronbach's Alpha test)

\begin{tabular}{lllllll}
\hline Scale Grouping & \multicolumn{2}{l}{ Cronbachs' } & \multicolumn{2}{l}{ Mean } & \multicolumn{2}{l}{ SD } \\
\cline { 2 - 7 } & SP & CN & SP & CN & SP & CN \\
\hline Employment & 0.94 & 0.75 & $3.71^{\mathrm{a}}$ & $4.09^{\mathrm{a}}$ & 0.52 & 0.68 \\
Aquaculture & 0.70 & 0.81 & $3.56^{\mathrm{a}}$ & $3.85^{\mathrm{a}}$ & 0.55 & 0.52 \\
Environment & 0.84 & 0.75 & $2.87^{\mathrm{b}}$ & $3.69^{\mathrm{a}}$ & 0.44 & 0.70 \\
Health nutrition & 0.81 & 0.64 & $4.02^{\mathrm{a}}$ & $4.41^{\mathrm{a}}$ & 0.48 & 0.58 \\
\hline
\end{tabular}

NB: SP (Sutarpara; $n=67), C N$ (Changnoagaon; $n=53)$; Mean values $( \pm$ SD) with different superscripts in the same column are significantly different $(\mathrm{P}<0.05)$

health nutrition that was below the value of Cronbachs' $\alpha=0.70$.

\section{The Pearson's Correlation Co-efficient Analysis}

Every group and economic and non-economic factors were considered as single scale for the purpose of the correlation analysis. Pearson's correlation co-efficient ( $r$ ) of between groups and correlation of all scale groups and economic and non-economic factors are shown in Table 5. The co-efficient provided highly positive correlation in aquaculture. Attitude toward employment, environment and health nutrition are greatly supported in Sutarpara. In case of attitude toward employment, respondents with greater concern about employment opportunities are more supportive of aquaculture $(\mathrm{r}=0.96,0.78)$ in Sutarpara and Changnoagaon respectively. Economic factor annual income had high correlation $(\mathrm{r}=0.67,0.88)$ in Sutarpara and Changnoagaon respectively with non-economic factor sex. Besides non-economic factor education had moderate correlation with another noneconomic factor sex. Moderate to weak correlation $(\mathrm{r}=0.31,0.11)$ were obtained for Sutarpara and Changnoagaon respectively in between health nutrition and environment scale but the difference was statistically significant $(\mathrm{p}<0.01)$.

In Sutarpara, the community fishers are strongly suggesting the cage aquaculture because the correlations were $r=0.64,0.92,0.96$ for the case of environment, health nutrition and employment accordingly. In Changnoagaon, the community fishers are strongly suggesting the cage aquaculture because the correlations were ( $\mathrm{r}=0.78$ and 0.82$)$ for the case of employment and health nutrition respectively but weak correlation $(r=0.12)$ was exist in environment scale.

\section{Stacked Bar Analysis}

The staked bar analysis illustrated that the attitude towards community driven cage aquaculture (CA) for between villages according to set questionnaire for employment and aquaculture. In Sutarpara, in the case of employment, the greater number of fishers $(72.4,11.9 \%)$ expressed their opinions in terms of agree and strongly agree scale respectively Figure 2 (A). The greater number of fishers $(65.55$, $24.97 \%$ ) expressed their opinions in agree and strongly agree scale respectively in the Figure 2 (B) for the case of Changnoagaon

In the case of aquaculture scale, attitude toward aquaculture was greatly supported by the fishers in Sutarpara and their opinion was around $75 \%$ in agree and strongly agree (Figure $3 \mathrm{~A}$ ) but in case of Changnoagaon, the percentage was $>60$ (Figure 3 B).

In the case of environment scale, about $67.17 \%$ fishers in Sutarpara were greatly supported their opinion in Neutral and expressed their opinion that having no environmental degradation in terms of water quality loss, disease introduction etc. (Figure 4A). But fishers in Changnoagaon showing <50\% in Neutral and $23.52 \%$ fishers agreed that the activities were in favour of environment (Figure 4B).

In the case of health nutrition scale, fishers in Sutarpara and Changnoagaon opinion was around $60 \%$ in agree and strongly agree implies a positive role in this scale if implementing cage aquaculture (Figure 4C and 4D).

\section{DISCUSSION}

The community fishers' attitude and willingness of community-based cage aquaculture was positively high in both research sites. The output reports revealed that there were a number of factors affected the attitude and willingness of fishers in different category. These factors had significant contribution to the variations of attitude and willingness of community fishers and consequently affected the objectives of developmental research projects where preventing overexploitation of fish 
Table 5. Correlation between groups indicators and factors

\begin{tabular}{|c|c|c|c|c|c|c|c|c|c|c|c|c|c|c|c|c|c|c|}
\hline & \multicolumn{2}{|c|}{ Employment } & \multicolumn{2}{|c|}{ Aquaculture } & \multicolumn{2}{|c|}{ Environment } & \multicolumn{2}{|c|}{ H. Nutrition } & \multicolumn{2}{|c|}{ Sex } & \multicolumn{2}{|c|}{ Age } & \multicolumn{2}{|c|}{ Education } & \multicolumn{2}{|c|}{ Occupation } & \multicolumn{2}{|c|}{ Income } \\
\hline & SP & $\mathrm{CN}$ & SP & $\mathrm{CN}$ & SP & $\mathrm{CN}$ & SP & $\mathrm{CN}$ & SP & $\mathrm{CN}$ & SP & $\mathrm{CN}$ & SP & $\mathrm{CN}$ & SP & $\mathrm{CN}$ & SP & $\mathrm{CN}$ \\
\hline Employment & 1.00 & 1.00 & & & & & & & & & & & & & & & & \\
\hline Aquaculture & 0.96 & 0.78 & 1.00 & 1.00 & & & & & & & & & & & & & & \\
\hline Environment & 0.52 & 0.00 & 0.64 & 0.12 & 1.00 & 1.00 & & & & & & & & & & & & \\
\hline H. Nutrition & 0.88 & 0.58 & 0.92 & 0.82 & 0.31 & 0.11 & 1.00 & 1.00 & & & & & & & & & & \\
\hline Sex* & -0.2 & -0.09 & -0.2 & 0.44 & -0.10 & 0.16 & -0.20 & 0.66 & 1.00 & 1.00 & & & & & & & & \\
\hline Age* & -0.01 & -0.14 & 0.01 & 0.00 & 0.14 & -0.01 & -0.06 & 0.06 & 0.08 & 0.31 & 1.00 & 1.00 & & & & & & \\
\hline Education* & 0.35 & 0.04 & 0.27 & 0.15 & 0.12 & 0.37 & 0.19 & 0.31 & 0.42 & 0.38 & -0.08 & -0.03 & 1.00 & 1.00 & & & & \\
\hline Occupation** & 0.27 & 0.01 & 0.26 & 0.01 & 0.08 & 0.03 & 0.28 & 0.02 & -0.59 & -0.14 & -0.09 & -0.20 & -0.13 & 0.09 & 1.00 & 1.00 & & \\
\hline Income ${ }^{* *}$ & 0.06 & -0.13 & 0.02 & 0.35 & -0.04 & 0.08 & 0.02 & 0.54 & 0.67 & 0.88 & 0.03 & 0.27 & 0.55 & 0.34 & -0.14 & 0.07 & 1 & 1 \\
\hline
\end{tabular}

N.B: $\mathrm{SP}=$ Sutarpara, $\mathrm{CN}=$ Changnoagaon; *indicates the non-economic factors and $* *$ indicates the economic factor; Correlation in bold were used for interpretation

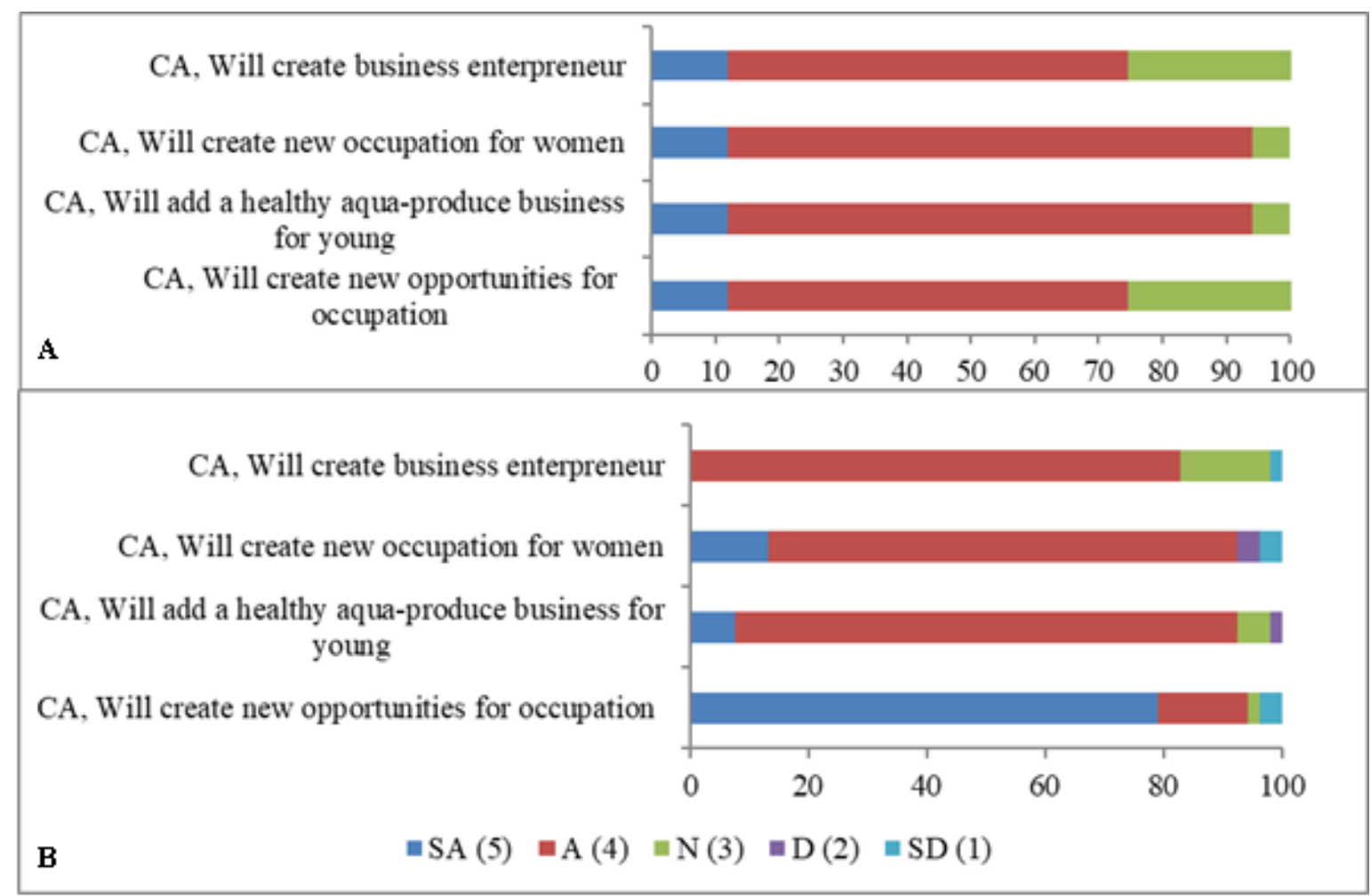

Figure 2. (A) and $(\mathrm{B})=\%$ response towards attitude into Likert scale 5 in Sutarpara and Changnoagaon for employment. CA (Cage aquaculture), SA (strongly agree), A (agree), N (neutral), D (disagree), SD (strongly disagree)

through community-based cage aquaculture and expedite the standard of livings. Majority interviewee in Sutarpara and Changnoagaon were looking for additional income sources and aiming to diversify their livelihood to reduce the risk of financial vulnerability, whereas some were trying to avoid shifting their livelihood other than fishing that comply with the findings of Liesa (2013) who examined alternative income generating activities adopted by the fishers community. It is worth mentioning that cage aquaculture most probably would remain an additional source of income and never be able to fully replace main occupations such as fishing. Nonetheless, cage aquaculture is likely to have a positive effect by reducing the need to rely heavily on the wild capture of haor resources (e.g fish) to make an income source. Additionally, it could serve as a supporting pillar in terms of unemployment when no income from wild catches because of bad weather conditions (e.g heavy current and wave) or other adverse life conditions. 


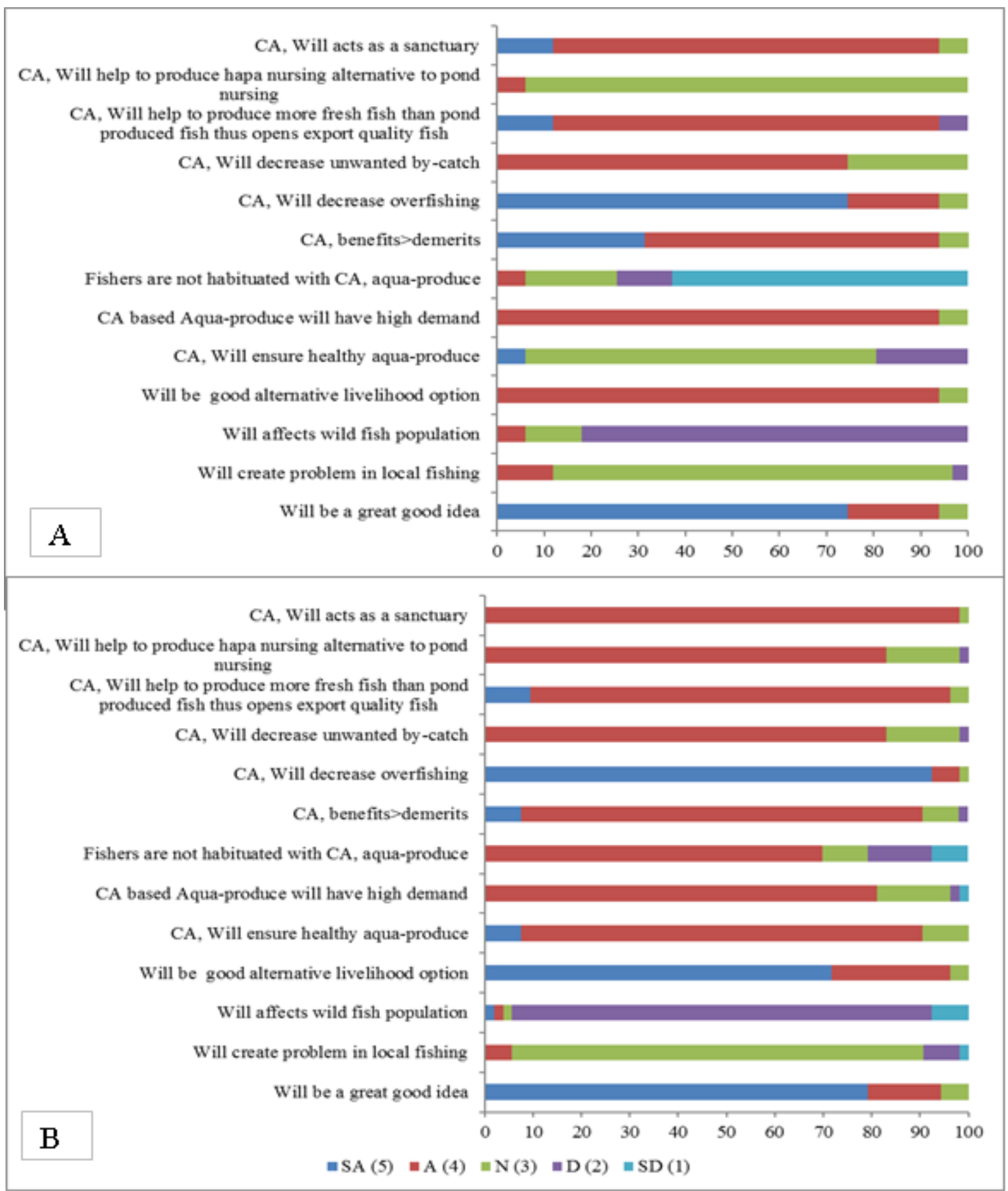

Figure 3. (A) and $(\mathrm{B})=\%$ response towards attitude into Likert scale 5 in Sutarpara and Changnoagaon for aquaculture). CA (Cage aquaculture), SA (strongly agree), A (agree), N (neutral), D (disagree), SD (strongly disagree)

Community-based cage aquaculture is a new initiative for the haor people, and the fishers community is likewise unfamiliar with aquaculture. All fishers in both selected villages are habituated with catching wild fish from natural source and they have very few knowledge on cage aquaculture. They are interested in this new alternative livelihood option and thus cage aquaculture is important for them. Mazur \& Curtis (2006) reported that stakeholder interaction and public attitude has important role in determining the acceptance of aquaculture. It is assumed that the introduction of haor oriented cage aquaculture also depends on the positive attitude of fisher community. Exploring the data after completing the investigation might provide important guideline to develop and implement future developmental projects and also helps to build guideline for policy makers in Bangladesh. 


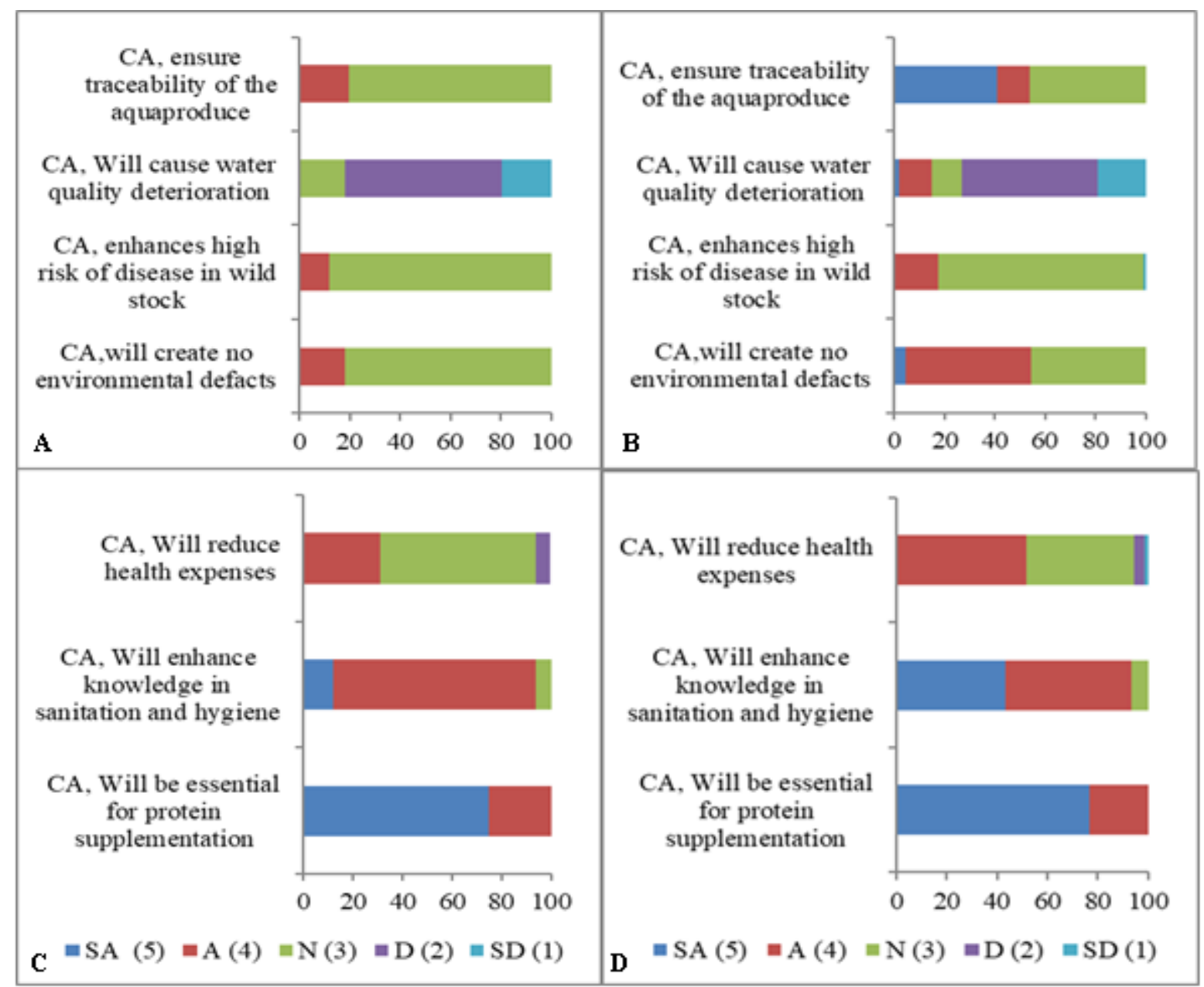

Figure 4. (A), (B), (C) and (D)=\% response towards attitude into Likert scale 5 in Sutarpara and Changnoagaon for environment). CA (Cage aquaculture), SA (strongly agree), A (agree), N (neutral), D (disagree), SD (strongly disagree)

In all cases, reliability of responses was high (Cronbach's $\alpha=0.06$ ). Mean differences of same scale grouping between the villages differed insignificantly $(p>0.05)$ except in the scale group named environment (Table 4). Cage aquaculture will provide a conflict between lease holder of the jalmahal because fishing is not possible in the area of cage aquaculture where the wild fish protects themselves. This area normally acts as a fish sanctuary that directly protect the wild fish and reduce overfishing in the catchment area of cage aquaculture area in the haor of Bangladesh. Comparatively greater correlation exists in all four scales grouping in Sutarpara than Changnoagaon showing greater support in favor of cage aquaculture. This was because of their greater interest in alternative livelihood. Moderate to weak correlation $(\mathrm{r}=0.31,0.11)$ were obtained for Sutarpara and Changnoagaon respectively in between health nutrition and environment scale because fisher community was not more aware of environment and health nutrition concerns. The findings of Shirra et al. (2012) also complied with the present findings where they found that the correlations were very weak for environment and health behavior.

The Pearson's correlation co-efficient ( $r$ ) among the scales, economic and non-economic factors is shown in Table 5. The four scales provide the relationships among them and also the relationships with the economic and non-economic factors in the two villages. In most cases, below moderate correlation $(<0.3-0.5)$ were exists. But the correlation for annual income with education and sex was moderate to high ranging from $(0.34-0.55$ and 0.67-0.88) in Sutarpara and Changnoagaon respectively. This might be due to fishers having financial support that helps them to spend money to complete higher education and household having fishers have the possibility to earn more money. Fishers in Changnoagaon having greater financial 
stability showed significantly higher $(\mathrm{p}<0.01)$ correlation for the case of health nutrition and annual income than Sutarpara. This was because of their greater interest in alternative livelihood.

In the case of Sutarpara sample, the highly positive correlation found between health nutrition and aquaculture might be due to the security of fish as food for their regular consumption it also reduces the overexploitation. From the stacked bar analysis, it was observed that $98.2 \%$ community fishers opined that cage aquaculture will not lead to overexploitation. For the case of employment and health nutrition concerns coupled with the previous thought (cage aquaculture acts as a sanctuary leading to protect overfishing) which justified the highly positive correlation prevails in both the research sites.

No literature is available on the negative impact of cage aquaculture in the open water of Bangladesh because cage aquaculture has started its journey only a decade ago in the river areas of Bangladesh. Cage aquaculture is going to be introduced in the haor areas. On the other hand, fisher community had no bitter experience about cage aquaculture and in depth knowledge about it. This finding also complied with the observation of Shirra et al. (2012), the knowledge of German people in environment perspective was comparatively lower than the knowledge of the people in Israel. The fishers in Sutarpara showed greater responses in the correlation between the scale of environment and aquaculture than Changnoagaon. This may be due to their thinking that the vast haor waters will not be affected or polluted because the loaded effluents in open water are negligible. Furthermore, they believe that the excreta and unused or wasted feed will directly use as fertilizer and feed for the wild stock respectively. This finding is also complied with the reports of Ansah et al. (2013).

Generally, most of the fisher community are leading their livelihood expenditure on fishing and agriculture in both the villages but the rate of dependency varied between the village fishers. In fact, the factors behind the involvement of community fishers in cage aquaculture was for financial gain and as an employment opportunity and thinking the income from cage aquaculture would be additional one livelihood option. It is assumed that the livelihood pattern of community fishers vary in line with the variability of their socio-economic conditions prevails in the community.

The rule of thumb, the economic progress and employment security might permit the people to rush in new livelihood activities and willing to take a certain amount of risk. Miyata (2003) observed the level of willingness to take risk for investing money in a demo game varied due to a number of factors such as the number of household members, education level and wealth rank. Our observed results complied with the finding of Miyata (2003) because a linear positive correlation was observed in both the villages for taking risk and engage in new alternative source of income with the number of household occupations, education level and annual income. The present data reveal that fishers having comparatively higher annual income showed more willingness to participate in the cage aquaculture implementation. Data from fisher community in Sutarpara showed lower value than Changnoagaon fishers for taking risk. A widely spread concept is, if sufficient handsome economic alternatives provides to the fishers community, thinking by many project designers or managers in community driven approaches, fishers are agreed to stop fishing as reported by Crawford (2002). As a result, economically profitable income alternatives will help a lot in reducing fishing pressure. But the collected data reveal that non-economic factors such as tradition and personal gratification are often more important than financial returns in deciding on whether to fish or not. A similar outcome can be expected for cage aquaculture implementation in Sutarpara and Changnoagaon, where many fishers stated they would not stop fishing even if involved in profitable cage aquaculture. In addition to that a high number of fishers would like to keep multiple income sources also support this finding strongly. Although still fishers showing their willingness to not to stop wild catching but the researchers thought that intensive training in cage aquaculture is important to enable them to operate the system largely independently, which might give them more self-confidence and an increase in motivation and ultimately the fishers focus exclusively on the continuation cage aquaculture through raising awareness for detrimental and destructive fishing methods and gears.

Annual income of fishers in both research villages ranged between US\$ 200 to 3112, which is not sufficient to meet basic livelihood requirements. Pollnac et al. (2002) found that income significantly controls the participation of 
villagers in project field activities poor fishers showed less willingness to take risks that may loss their invested amount and earn less profit (Miyata, 2003). In contrast, Pollnac et al. (2002) illustrated that if the profit of participation was demonstrated by a few people, other villagers would perceive the activity and join in the new livelihood approach. At the beginning, the involvement in innovative research projects implemented to reduce the fishing pressure and ensure livelihood alternatives is often low but increases with the successful up scaling of the technology and the benefits goes to the community (Rogers, 1995; Hamblin et al., 1973).

Another important informative data explored during the survey that were the young fisher community are more eager to take risk in innovative livelihood activities. The onset timings of innovative cage aquaculture were also important factor for adoption of cage aquaculture in both villages because in the haor areas normally a huge natural catch started in the month of October and at that time the price of cultured fish would be much lower than expected. The successful introduction of community-based cage aquaculture will be detrimentally affected by the low market price of the cultured fish. As the culture period varies from 3 to 5 months, the onset timing of cage aquaculture should be preplanned to avoid the haor natural catch time and selling fish in the lean period of haor with a view to higher profit. It was observed that the fishers were less skeptical and more willing to continue the new approach if they could find the successful initialization of the project. Miyata $\&$ Manatunge (2004) also drew attention in timing for introduction of an alternative livelihood option, which can determine whether villagers adopt or refuse the new activity as low market prices would inversely hamper the degree of adoption. Foremost, efforts of researchers should be given in the phase of implementation to prevent a failure of the cage aquaculture attempts in haor locality because lack of success would make it hard to encourage others to take part in the cage aquaculture ventures.

Pollnac et al. (2001) examined the level of satisfaction of fishers in Indonesia and found that the fishers would not leave the fishing activity because of their culture values, tradition and ample knowledge though the fishing activity is laborious and vulnerable to the environmental condition. Our investigated results also supported that findings because more than $50 \%$ fishers thought that fishing should be the main income source.
Fishers were not willing to culture traditional type of fish as a cultured fish in cage aquaculture system. The type of fish used in cage aquaculture was also an important factor, as fishers may feel more comfortable of culturing fish that they are catching regularly from natural source like Common carp (Cyprinus carpio), Garua (Clupisoma garua) though fry or fingerling are not available

yet.

Women in Sutarpara showed high willingness to cage aquaculture than in Changnoagaon. This might be because women had more free time after finishing their housework. Thus, during bad weather and late winter season, there are fewer catches for the women to process (processing being a female occupation), and cage aquaculture would be a suitable livelihood alternative for them.

\section{CONCLUSION}

The discussed issues above have great important considerations to investigate the set objectives. Prejudgment of knowledge on different scale groups and factors was very significant to certain the actual outputs. The present study covered a number of scale groups (developed with categorical questions) to provide in-depth information associated with attitude towards cage aquaculture of them. It also revealed a number of desirable features in fishers' attitudes toward cage aquaculture in the context of employment, environment and health nutrition, which indicate a high potential for future cage aquaculture venture in haor areas. In addition, it also provides comparative data on studying the feasibility of cage aquaculture between the villages. The comparative study results demonstrated that the local prevailing individual factor significantly affects the willingness towards cage aquaculture. It is therefore important to implement a research project emphasizing attitudes and economic and noneconomic factors to develop a justified strategy of community driven cage aquaculture in haor based areas in Bangladesh.

\section{ACKNOWLEDGEMENTS}

The authors would like to thank to Department of Fisheries (DoF), Bangladesh for arranging financial support. 


\section{REFERENCES}

Adibashi Fisheries Project or AFP (2007). Fisheries and Aquaculture Enterprise Development for the Adivasi (Tribal) Communities. The WorldFish Annual Progress Report. The WorldFish Center, Dhaka, Bangladesh. 11pp.

Alam, M.F. \& Basha, M.A. (1995). Structure of cost and profitability of small scale riverine fishing in Bangladesh. Journal of Research Progress, 9: 235241.

Ansah, Y.B., Frimpong, E.A., \& Amisah, S. (2013). Characterization of potential aquaculture pond effluents, and physico-chemical and microbial assessment of effluent-receiving waters in central Ghana. African Journal of Aquatic Science, 38: 1-8.

Bunce, L., Townsley, P., Pomeroy, R., \& Pollnac, R. (2000). Socioeconomic Manual for Coral Reef Management. Global Coral Reef Monitoring Network. Australian institute of marine science and GCRMN, Towns-ville, Australia, 183 pp.

Chaki, N., Jahan, S., Fahad, M.F.H., Galib, S.M., Mohsin, \& A.B.M. (2014). Environment and fish fauna of the Atrai River: global and local conservation perspective. Journal of Fisheries 2(3): 163-172.

Crawford, B.R. (2002). Working Paper: Seaweed farming: An alternative livelihood for smallscale fishers? Coastal Resources Center, University of Rhode Island, USA.

Department of Fisheries (DoF) (2015). Fishery statistical yearbook of Bangladesh. Fisheries Resources Survey System, Ministry of Fisheries and Livestock, Dhaka, Bangladesh.

Flick, U. (2009). Qualitative sozialforschung. Rowohlt Taschenbuch Verlag, Hamburg.

Hamblin, R., Jacobsen, B., \& Miller, J. (1973). A mathematical theory of social change. John Wiley \& Sons, New York.

Kemper, E.A., Stringfield, S., \& Teddlie, C. (2003). Mixed methods sampling strategies in social science research. In: A. Tashakkori, Teddlie C (Editors.), Handbook of Mixed Methods in Social and Behavioral Research. Sage Publications, Thousand Oaks, CA. 273-296.

Liesa-Marlena, V.E., Ferse, S. C.A., Glaser, M., \& Kunzmann, A. (2013). Attitudes and perceptions of villagers toward community-based mariculture in Minahasa, North Sulawesi, Indonesia. Ocean \& Coastal Management 73: 101-112.
Mazur, N.A., \& Curtis, A.L. (2006). Risk Perceptions, aquaculture and issues of trust: Lessons from Australia. Society and Natural Resources, 19: 791808.

Miyata, S. (2003). Household's risk attitudes in Indonesian villages. Applied Economics, 35(5): 573 583.

Miyata, S., \& Manatunge, J. (2004). Knowledge sharing and other decision factors influencing adoption of aquaculture in Indonesia. International Journal of Water Resources Development, 20(4): 523-536.

Pollnac, R.B., Crawford, B.R., \& Sukmara, A. (2002). Community-based coastal resources management: An interim assessment of the Proyek Pesisir Field Site in Bentenan and Tumbak Villages, North Sulawesi, Bangladesh. Technical Report TE- 02/01E. Coastal Resources Center, University of Rhode Island, USA.

Pollnac, R.B., Pomeroy, R.S., \& Harkes, I.H.T. (2001). Fishery policy and job satisfaction in three Southeast Asian fisheries. Ocean and Coastal Management, 44: 531-544

Rahman, M. (2004). The cultural world of the Adivasis of Bangladesh, Society for Environment and Human Development, Dhaka, Bangladesh.

Rejwan, K.M., Ripon, K., Hikary, A.M., Hossain, B., \& Hossain, M.M. (2012). Livelihood status of fishermen of the old Brahmaputra River, Bangladesh. World Applied Sciences Journal, 16 (6): 869-873.

Rogers, E.M. (1995). Diffusion of innovations, (fourth edition). The Free Press, New York.

Shah, M.S. (2003). Human resource development activities in fisheries sector. In: Fish Fortnight Compendium 2003. Department of Fisheries, Ministry of Fisheries and Livestock, Bangladesh. Dhaka, Bangladesh. pp. 57-59.

Shirra, F., Eran, V.G., Horst, S., Michael, S., Irina, K., Peter, K., \& Dror, A. (2012). Public attitudes towards marine aquaculture: A comparative analysis of Germany and Israel. Environmental Science and Policy, 22: 60-72.

State Of World Fisheries and Aquaculture (SOFIA) (2018). Meeting the sustainable development goals. Rome: FAO report 2018. p40.

Steel, R.D.G., \& Torrie, J.H. (1960). Principles and procedures of statistics. McGraw-Hill Book Co., New York, United States. pp.481. 
